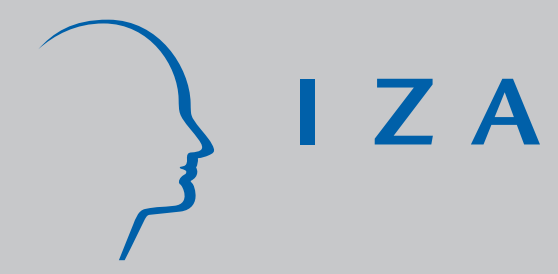

IZA DP No. 227

Immigration from the Eastern Block and the former Soviet Union to Israel: Who is coming when?

Lilo Locher

December 2000 


\title{
Immigration from the Eastern Block and the former Soviet Union to Israel: Who is coming when?
}

\author{
Lilo Locher \\ IZA, Bonn \\ Discussion Paper No. 227 \\ December 2000 \\ IZA \\ P.O. Box 7240 \\ D-53072 Bonn \\ Germany \\ Tel.: +49-228-3894-0 \\ Fax: +49-228-3894-210 \\ Email: iza@iza.org
}

This Discussion Paper is issued within the framework of IZA's research area Mobility and Flexibility of Labor Markets. Any opinions expressed here are those of the author(s) and not those of the institute. Research disseminated by IZA may include views on policy, but the institute itself takes no institutional policy positions.

The Institute for the Study of Labor (IZA) in Bonn is a local and virtual international research center and a place of communication between science, politics and business. IZA is an independent, nonprofit limited liability company (Gesellschaft mit beschränkter Haftung) supported by the Deutsche Post AG. The center is associated with the University of Bonn and offers a stimulating research environment through its research networks, research support, and visitors and doctoral programs. IZA engages in (i) original and internationally competitive research in all fields of labor economics, (ii) development of policy concepts, and (iii) dissemination of research results and concepts to the interested public. The current research program deals with (1) mobility and flexibility of labor markets, (2) internationalization of labor markets and European integration, (3) the welfare state and labor markets, (4) labor markets in transition, (5) the future of work, (6) project evaluation and (7) general labor economics.

IZA Discussion Papers often represent preliminary work and are circulated to encourage discussion. Citation of such a paper should account for its provisional character. 
IZA Discussion Paper No. 227

December 2000

\title{
ABSTRACT \\ Immigration from the Eastern Block and the former Soviet Union to Israel: Who is coming when?*
}

\begin{abstract}
Average education of new immigrants from the East European countries and the former Soviet Union (FSU) in Israel declined during the last ten years. I present a simple two-period model of migration with uncertainty about future conditions in both countries and estimate a reduced form, using data from the Israeli 1995 Census and several years of the Israeli Labor Force Survey. Wages in Israel in each period are the result of a human capital investment decision. In this framework, the return to migrating early is higher, the higher the education of a potential migrant, but education also increases the option value of staying. Estimation of a Cox proportionate hazard model and a discrete time hazard model suggest that human capital investment considerations indeed influence the timing of migration. Other variables that make people migrate earlier are being Jewish, being married, and having no children. Economic conditions in the source countries and in the destination country, which are also included in the regressions, do not seem to matter and cover mainly time effects.
\end{abstract}

JEL Classification: J24, J61

Keywords: Migration decision, human capital investment, migration as an option, duration model

\author{
Lilo Locher \\ IZA \\ P.O. Box 7240 \\ D-53072 Bonn \\ Germany \\ Tel.: +492283894531 \\ Fax: +492283894510 \\ Email: locher@iza.org
}

\footnotetext{
* I would like to thank Zvi Eckstein, Magnus Lofstrom, Yoram Weiss and Rainer Winkelmann for very helpful comments. Financial help from the HSP III of the German Academic Exchange Service (DAAD) is gratefully acknowledged.
} 


\section{$\underline{1 . \text { Introduction }}$}

In the ten years after the breakdown of the Communist Regimes in the Eastern European countries and the former Soviet Union (FSU) approximately 800,000 people from these countries immigrated to Israel. The main influx was in the years 1990 and 1991, with around 150,000 immigrants per year. From 1992 onwards, the yearly number of immigrants from these countries leveled off at around 60,000. Today, immigrants from these countries make up nearly $20 \%$ of the Israeli population.

In the course of these ten years, immigrants' characteristics upon arrival changed. More recent immigrants tend to be younger and less educated, and they are less likely to be married. In addition, the percentages of immigrants coming from the different countries of origin changed over time. For example, the share of Ukrainians rose from roughly $30 \%$ in the beginning of the 1990s to $40 \%$ in 1997 and 1998 .

The aim of this paper is to explain these changes in immigrants' characteristics over time with a simple two-period model of human capital investment and to test its implications using data from the 1995 Israeli Census and different years of the Israeli Labor Force Survey. The main impact is on the decline of average education of new immigrants over time.

Throughout my analysis, I assume that the decision whether and when to migrate is altogether up to the potential migrants themselves. Hence, the observed differences in immigrants' characteristics are only due to different results for the individuals' maximization problems over time. In fact, the "Law of Return" gives every person of Jewish descent the right to immigrate to Israel at any time. ${ }^{1}$ Emigration from the FSU and the East European countries, which previously was very difficult, has also been unrestricted since August 1989. Nevertheless, this assumption might be problematic. First, it was not obvious in 1989 that emigration would remain unrestricted. Some people left as early as possible, because they did not trust the promise that they would be allowed to leave in the future. Therefore, the number of immigrants peaked in the early 1990s. This peak due to panic migration was also boosted by the fact that migration to the other two main immigration countries for Jewish FSU

\footnotetext{
1 Since 1970, the "Law of Return" grants automatic citizenship to all Jews, their children, grandchildren, spouses, and the spouses of their children and grandchildren. In addition to that, "aliya" (immigration) is promoted by organizations like the Jewish Agency for Israel, which inform Jewish people in the Diaspora about the possibility to make aliya. Furthermore, new immigrants get generous help; for example, free language classes (Ulpan) and generous rent subsidies during their first three years in Israel.
} 
emigrants, the USA and Germany, was less easy. The application procedures for these countries are more complicated, and the legal basis for immigration is less clear. For the USA, there is a limitation of 50,000 immigrants from the FSU per year since 1990 (Gitelman, 1997), so that immigrants in the early 1990s had to queue for their visa. For Germany, regulations were a little bit vague (American Jewish Yearbook, 19901999). Therefore, panic migrants were not spread over the three countries, but almost exclusively came to Israel. This is reflected in the declining share of Jewish migrants to Israel over total Jewish migrants over time. In 1990 and 1991, 90\% and 78\% of all Jewish emigrants from the FSU went to Israel. In the following years, the share was around $55 \%$ (Tolts, 1999). ${ }^{2}$ As a consequence of the panic migration, there are some immigrants in the data who did not choose their time of migration optimally.

In the model used in this paper, a potential migrant's decision whether to wait or to migrate in the current period is driven by two opposing forces. The first one is the option value of migration. Staying in the source country leaves open the possibility to migrate in the second period, whereas going to Israel includes paying a nonrefundable migration cost. Return migration is excluded in my model, and future economic conditions are uncertain, so that migrating includes the risk of making a mistake that cannot be repaired. ${ }^{3}$ This first force makes people more inclined to postpone migration to the second period when the realization of the second period shock is known. If wages increase with the amount of human capital a person has, the effect is stronger for the more educated. The second force is the development of immigrants' earnings in Israel. As immigrants' imported human capital has a very low value on the Israeli labor market, immigrants incur a substantial earnings loss upon arrival. However, they experience a big wage increase during the first years in the new country, as they acquire local skills. With per-period earnings in Israel increasing over time, average per-period earnings in Israel relative to the earnings of natives are increasing with total working time in Israel. This provides an incentive to migrate as early as possible. If there is some kind of complementarity between imported and newly acquired skills, this effect is stronger for more educated people. In the empirical part of the paper, the fact that the more educated come earlier is interpreted as evidence that the second force dominates the first. We also provide some evidence for the relevance

\footnotetext{
${ }^{2}$ Eventually, about $75 \%$ of the Jewish people leaving the FSU between 1989 and 1998 went to Israel.

${ }^{3}$ In reality, return migration is very low for this migration wave. One reason might be high migration costs that are not refundable because they consist of (illegal) transfers of assets to Israel.
} 
of the reason given in the model for the decline in human capital as opposed to other possible reasons.

The rest of the paper is structured as follows: In section 2, I give a short overview of the related literature. Section 3 presents the model and discusses how it can be tested empirically. Section 4 describes the data and gives some summary statistics. Section 5 discusses the estimation methods used. Section 6 presents the estimation results. Finally, section 7 concludes.

\section{Related Literature}

This paper is related to two areas of research. First, it adds to the literature about the labor market assimilation of immigrants. This literature concentrates on the performance of immigrants after they arrived in the new country depending on the portability of imported human capital. The commonly observed assimilation pattern of earnings is explained with models of human capital investment. Second, this work is related to research regarding dynamic aspects of the migration decision.

\subsection{Wage assimilation and human capital investment of immigrants}

The literature on the influence of human capital on the migration decision concentrates on the classical immigration countries, i.e. the USA and Canada. Borjas (1985, 1995) adopts the Roy model of income distribution to the case of labor migration between two countries. He shows that, holding mean income constant, immigrants from countries with more inequality in their income distribution are expected to have a relatively low educational level, whereas immigrants from countries with a more equal income distribution have a relatively high level of education. The effect is stronger, the higher the transferability of skills among the source country and the host country. Although this model can explain the differences in immigrants' performance across different cohorts with changes in the composition of the country of origin mix for the USA, it cannot explain the changes in the level of education within one wave of immigrants coming from the same country of origin. This is the objective of this paper. In addition, Borjas' model assumes a fixed convertibility of source country to host country human capital, whereas in reality, the amount of human capital that will be converted seems to be an endogenous variable that changes over time. In particular, the return on imported knowledge seems to depend on the amount of newly acquired 
human capital. For example, Friedberg (2000) estimates Mincer wage equations for immigrants to Israel in which she distinguishes between imported and newly acquired human capital and experience. She finds that the interaction term of domestic and imported human capital is positive and significant. The return on imported human capital is lower than the return on newly acquired human capital, and the return on imported experience is generally insignificant.

The acquisition of new human capital and its interactions with imported human capital have been studied in the context of immigrants' labor market assimilation. The respective literature does not look at the migration decision itself, but at the labor market decisions of people who already migrated. The main challenge is to explain why immigrants experience such a big increase in wages with years since migration, and to see if they eventually catch up or even overtake comparable natives. Duleep and Regets (1999) and Eckstein and Weiss (1998) have very similar models to explain that phenomenon. ${ }^{4}$ The main point is that immigrants upon arrival invest more in human capital than comparable natives, because the cost of investment is lower and the return is higher than for natives. The fact that costs are lower is due to the big earnings loss immigrants experience upon arrival, which decreases the opportunity cost of using working time for schooling. The return on investment can be higher than the return for natives for two reasons: Either because imported human capital serves as an input in the production function of domestic human capital, or because the two kinds of human capital are complements on the labor market.

However, these models take the date of migration as given. But if the date of migration is not imposed on immigrants as a result of a country's migration policy, potential immigrants should choose it optimally according to the same objective function that determines their behavior after migration. This is why I use the models developed to explain post-migration behavior to explain the migration decision itself.

\subsection{Dynamic aspects of the migration decision}

More than half of the immigrants from the East European countries and the FSU to Israel in the 1990s came after 1991, which means that they did not come right after they got the option to do so, but more than two to three years later. Furthermore, the number of immigrants per year has remained roughly constant since 1993 until today.

\footnotetext{
${ }^{4}$ The model by Duleep and Regets is only a two-period-model, whereas Eckstein and Weiss solve a tperiod dynamic programming problem.
} 
Models trying to explain this sluggishness in the behavior of immigrants either stress the importance of future uncertainty or the role of changes in the variables determining the migration decision.

In models that explicitly take uncertainty about the future realizations of state variables into consideration, migration is interpreted as an investment. Like an investment, migration is characterized by a high fixed cost in the beginning and a distant future return, which, as is characteristic for future values, is uncertain. It has been shown by Pindyck (1991), among others, that a simple net present value calculation overpredicts the amount of investment to a large scale. Taking into account both this high initial cost and the fact that an investment can be delayed leads to much lower predictions for the amount of investment. In these models, the possibility to investment is considered as an option, and models are solved using option pricing methods. The same has been done for immigration. The trade-off in the individual's migration decision is not whether to "migrate" or "not migrate", but whether to "migrate" or to "stay now and perhaps migrate in the future". If there is uncertainty about future gains of migration, the value of waiting is positive. Burda (1995) develops a model in which future wage gaps between the source country and the destination country are uncertain, but diminish over time. O'Connell (1997) presents a similar model with a constant wage differential and uncertainty both about future wage differentials and current economic conditions in the destination country. Both models are continuous in time, and the wage gap follows a Brownian motion.

These models could explain why not all potential immigrants in the FSU came at once. But the only explanation for the fact that annual migration was roughly constant for the last eight years would appear to be regular and constant shocks that enlarge the wage gap over the whole range of time. However, this was not the case. Another problem for the empirical application of this model is the infinite horizon aspect. This implies that the value function is stationary, i.e. it does not allow for the migration decision to change as people get older.

The other explanation for inertia in migration is that the determinants of migration change over time. These determinants can be the economic conditions in the source country and in the destination country, or they can be variables that change because the number of migrants is changing. Hatton (1995) tries to explain the time series of the emigration rate for the U.K. to the New World in the turn of the last 
century (1870-1913). He develops a model where the migration rate in each period is a function of current economic conditions and the number of immigrants already living in the new countries. In his estimations, fluctuations in the business cycle both in the source and in the destination countries explain a considerable amount of variation in the migration rate. As new immigrants are very severely affected by a high unemployment rate (Chiswick et al., 1997), it might pay not to leave in a recession, but to wait for a period of economic expansion.

The dependency of the migration rate on the number of previous migrants can be explained with network effects. The more people of the same origin already live in a new country, the less foreign it is, which makes migration easier. Immigrant networks lower the risk and the cost of migration, because they help newcomers to find their way in the new country (Bauer and Zimmermann, 1998). ${ }^{5}$

The model in this paper concentrates on the human capital investment effects and the option value of migration. Macroeconomic time series variables are also included in the estimations to cover the effect of changes in economic conditions over time, but the interdependency of migration decisions, e.g. through network effects, is not analyzed.

\section{The Model}

In this section, we present a simple two-period model explaining how immigrants decide when to migrate. Utility in each period $t=1,2$ and in each country $i=S, I$ is given by the sum of earnings $w$, non-monetary utility b, and a random shock $\varepsilon$. Furthermore, if migration takes place, utility is reduced by a migration cost $\mathrm{c}$ that has to be paid once in the migration period.

$$
\mathrm{U}_{\mathrm{t}}{ }^{\mathrm{i}}=\mathrm{w}_{\mathrm{t}}{ }^{\mathrm{i}}+\mathrm{b}_{\mathrm{t}}{ }^{\mathrm{i}}-\mathrm{I} \cdot \mathrm{c}+\varepsilon_{\mathrm{t}}{ }^{\mathrm{i}}, \quad \mathrm{i}=\mathrm{S} \text { (source country), } \mathrm{I} \text { (Israel), } \mathrm{t}=1,2 .
$$

$\mathrm{I}$ is an indicator function, i.e. $\mathrm{I}=1$ if migration takes place in $\mathrm{t}$, and $\mathrm{I}=0$ otherwise. The random shock $\varepsilon$ is assumed to have zero mean. The difference between the shocks in the two countries in a period $\mathrm{t}$ is $\Delta \varepsilon=\varepsilon^{\mathrm{I}}-\varepsilon^{\mathrm{S}} . \Delta \varepsilon$ is normally distributed with $\mathrm{N} \sim(0$, $\sigma^{2}$ ). Earnings, non-monetary utility and the random shock may differ in the two periods and in the two countries in which the potential migrant can stay.

\footnotetext{
${ }^{5}$ In the case of the Russian immigration, the network effect might also work as a push factor. The more Jewish people leave the Russian Jewish Community, the more difficult it becomes to stay there, because the remnants become a real minority. This might be an explanation why the emigration rate tends to be lower for those FSU countries that have a bigger Jewish community.
} 
In the beginning, all potential migrants are staying in the source country. Before period 1, the period 1 shocks are realized. In period 1, the potential migrants decide whether to stay or whether to go to Israel. Between the first and the second period, the period 2 shocks are realized. Finally, in the second period, those who have migrated in period 1 stay in Israel, whereas those who have remained in the source country again decide whether to stay or to migrate.

For two reasons, the migration decision in period 2 will be different from the migration decision in period 1. First, in period 2 there is no uncertainty, whereas in period 1 the migrant does not know yet the realization of the shock $\varepsilon$ in the second period. Second, the immigrant's wage in Israel in period 2 will be higher if he migrates in the first period than if he migrates in the second period. If he comes in period 1, he will have invested in Israeli human capital in the first period, which will increase his earnings in the second period.

\subsection{The determination of earnings in Israel and in the source country}

Earnings in period $\mathrm{t}$ in Israel are given by the product of the hourly wage, $\mathrm{k}(\cdot)$, and time spent working, $\mathrm{h}_{\mathrm{t}}{ }^{\mathrm{w}}$. Hourly wages depend on the stock of Israeli human capital the person possesses in the beginning of the period, $\mathrm{s}_{\mathrm{t}-1}{ }^{\mathrm{I}}$. Notice that imported human capital does not enter the Israeli wage equation.

$$
\mathrm{W}_{\mathrm{t}}{ }^{\mathrm{I}}=\mathrm{k}\left(\mathrm{s}_{\mathrm{t}-1}{ }^{\mathrm{I}}\right) \cdot \mathrm{h}_{\mathrm{t}}{ }^{\mathrm{w}} \quad \mathrm{k}^{\prime}>0, \mathrm{k}^{\prime}<0, \mathrm{k}(0)>0, \mathrm{k}^{\prime}(0) \rightarrow \infty
$$

In each period, individuals have one unit of time, which they allocate between working $\left(\mathrm{h}_{\mathrm{t}}{ }^{\mathrm{w}}\right)$ and schooling $\left(\mathrm{h}_{\mathrm{t}}^{\mathrm{s}}\right)$.

(3) $1=h_{t}{ }^{w}+h_{t}{ }^{s}$

The two inputs for the production of Israeli skills are imported source country skills and schooling time.

(4) $\quad \mathrm{s}_{\mathrm{t}}{ }^{\mathrm{I}}=\mathrm{h}_{\mathrm{t}}{ }^{\mathrm{S}} \cdot \mathrm{g}\left(\mathrm{s}^{\mathrm{S}}\right)$

$$
\mathrm{g}^{\prime}>0, \mathrm{~g}^{\prime}<0, \mathrm{~g}(0) \geq 0
$$

The idea behind this production function is that there is some kind of complementarity between imported skills and newly acquired skills. An engineer's engineering skills are worthless if he does not have a basic knowledge of Hebrew. Hence, upon arrival, he is not better off than any unskilled worker. However, if he studies Hebrew, the amount of human capital that he can use on the labor market increases not only to the extent that he learns to speak Hebrew, but also to the extent that his Hebrew makes his 
engineering knowledge usable. An unskilled worker, on the other hand, gains nothing but improved language skills if he goes to Hebrew classes.

As it is only human capital of the previous period that influences the wage, the return on investment in human capital in the last period is zero. Therefore, all time in period 2 will be used for working, i.e.

$$
\mathrm{h}_{2}{ }^{\mathrm{W}} *=1 .
$$

This is independent of whether migration takes place in period 1 or 2 .

In the first period, the immigrant chooses $h_{1}{ }^{{ }^{*} *}$ so as to maximize discounted lifetime earnings over the two periods:

$$
\mathrm{h}_{1}{ }^{\mathrm{w} *}=\arg \max \left[\mathrm{w}_{1}{ }^{\mathrm{I}}+\beta \mathrm{w}_{2,1}{ }^{\mathrm{I}}\right]
$$

The optimum is characterized by

$$
\mathrm{k}(0)=\beta \mathrm{g}\left(\mathrm{s}^{\mathrm{S}}\right) \cdot \mathrm{k}^{\prime}\left[\left(1-\mathrm{h}_{1}{ }^{\mathrm{w}} *\right) \cdot \mathrm{g}\left(\mathrm{s}^{\mathrm{S}}\right)\right] .^{6}
$$

Equation (7) says that the opportunity cost of investment, the wage in period 1, equals the marginal return to investment, the discounted marginal increase in the second period hourly wage. It is now clear why the earnings of a person who is in Israel in period 2 depends on whether migration took place in period 1 or 2 . We have $\mathrm{w}_{2,1}{ }^{\mathrm{I}}>$ $\mathrm{W}_{2,2} \mathrm{I}$, where the second subscript indicates the period of migration. The amount of schooling, $\mathrm{h}_{1}^{\mathrm{s}}$, may increase or decrease with the amount of imported human capital, $\mathrm{s}^{\mathrm{S}}$. Yet, in any case $\mathrm{w}_{2,1}{ }^{\mathrm{I}}$ increases in $\mathrm{s}^{\mathrm{S}}$, i.e., in the second period in Israel, earnings are higher for more educated immigrants.

In the source country, earnings are a constant function of source country human capital, $s$, in both periods. The process of human capital accumulation is assumed to be complete, so that all the time is spent working and there is no need for a time subscript for $\mathrm{s}$.

$$
\mathrm{w}_{\mathrm{t}}^{\mathrm{S}}=1\left(\mathrm{~s}^{\mathrm{S}}\right) . \quad 1 \text { ' }>0, \mathrm{l}^{\prime},<0
$$

\subsection{The migration decision}

Migration in period 2 takes place iff $\mathrm{U}_{2}{ }^{\mathrm{I}}>\mathrm{U}_{2}{ }^{\mathrm{S}}$, i.e. iff

$$
\varepsilon_{2}{ }^{\mathrm{I}}-\varepsilon_{2}{ }^{\mathrm{S}}>\mathrm{w}_{2}{ }^{\mathrm{S}}-\mathrm{w}_{2,2}{ }^{\mathrm{I}}+\mathrm{b}_{2}{ }^{\mathrm{S}}-\mathrm{b}_{2}{ }^{\mathrm{I}}+\mathrm{c}
$$

As we are not interested in absolute utility levels, but only in the difference in utility between the two countries, we write this as

$$
\Delta \varepsilon_{2}>\mathrm{c}-\Delta \mathrm{w}_{2,2}-\Delta \mathrm{b}_{2}=\Delta \varepsilon_{2}^{*}
$$

\footnotetext{
${ }^{6}$ The assumptions about $\mathrm{g}(0)$ and $\mathrm{k}$ '(0) guarantee an interior solution.
} 
where $\Delta \mathrm{w}_{2,2}=\mathrm{w}_{2,2}{ }^{\mathrm{I}}-\mathrm{w}_{2}{ }^{\mathrm{S}}$, and $\Delta \mathrm{b}_{2}=\mathrm{b}_{2}{ }^{\mathrm{I}}-\mathrm{b}_{2}{ }^{\mathrm{S}}$, and $\Delta \varepsilon_{2} *$ is the value of the difference in shocks between the two countries that triggers migration. Other differences will be defined accordingly. The probability of staying in period 2 is given as $\Phi(\mathrm{z})$, where $\mathrm{z}=$ $\left(\mathrm{c}-\Delta \mathrm{w}_{2,2}-\Delta \mathrm{b}_{2}\right) / \sigma$.

Migration in period 1 takes place if the net present value of the utility of staying in Israel in periods 1 and 2 is higher than the utility of remaining in the source country in period 1 and making the optimal decision (stay or leave) in period 2.

$$
\begin{aligned}
& \Delta \mathrm{w}_{1}+\Delta \mathrm{b}_{1}+\Delta \varepsilon_{1}+\beta\left[\Delta \mathrm{w}_{2,1}+\Delta \mathrm{b}_{2}\right]-\mathrm{c}> \\
& \quad \beta[1-\Phi(\mathrm{z})] \mathrm{E}\left[\Delta \mathrm{w}_{2,2}+\Delta \mathrm{b}_{2}+\Delta \varepsilon_{2}-\mathrm{c} \mid \Delta \varepsilon_{2}>\Delta \varepsilon_{2}{ }^{*}\right]
\end{aligned}
$$

The left hand side of (10) describes the utility gain of migrating now versus staying in both periods. The right hand side corrects for the fact that there may also be migration in period 2, in case the utility difference turns out to be positive. Calculating the conditional expectation and arranging terms as in (9'), we get to

$$
\begin{aligned}
\Delta \varepsilon_{1}>\mathrm{c} & -\Delta \mathrm{w}_{1}-\Delta \mathrm{b}_{1}-\beta\left[\Delta \mathrm{w}_{2,1}-\Delta \mathrm{b}_{2}\right] \\
& +\beta[1-\Phi(\mathrm{z})]\left[\Delta \mathrm{w}_{2,2}+\Delta \mathrm{b}_{2}-\mathrm{c}\right]+\beta \sigma \phi(\mathrm{z})=\Delta \varepsilon_{1} *
\end{aligned}
$$

with $\Delta \varepsilon_{1}^{*}$ being the value for the difference in shocks between the two countries that triggers migration in the first period.

To focus these ideas, let us assume now that $\mathrm{w}_{2}{ }^{\mathrm{S}}=\mathrm{w}_{1}{ }^{\mathrm{S}}$, and $\Delta \mathrm{b}_{1}=\Delta \mathrm{b}_{2}$. Individuals are expected to migrate in the first period rather than in the second if $\Delta \varepsilon_{2}^{*}>\Delta \varepsilon_{1}^{*}$. This is the case iff

$$
\begin{aligned}
{\left[\Delta \mathrm{w}_{1}-\Delta \mathrm{w}_{2,2}\right]+\beta\left[\Delta \mathrm{w}_{2,1}-\Delta \mathrm{w}_{2,2}\right] } & \\
> & \beta \Phi(\mathrm{z})\left[\Delta \mathrm{w}_{2,2}+\Delta \mathrm{b}_{2}\right]+\beta \sigma \phi(\mathrm{z})-\beta[1-\Phi(\mathrm{z})] \mathrm{c}
\end{aligned}
$$

The left-hand side of this inequality reflects the wage effect due to the investment in human capital. The first term in brackets is the difference in earnings an immigrant experiences in the first period in which he is staying in Israel. This term is negative, as $\mathrm{h}_{1}{ }^{\mathrm{S} *}>0$. The second term on the left hand side of (11) is the difference in wages in period 2 in Israel, depending on whether migration took place in the first period or in the second. The second difference in wages, discounted by $\beta$, is at least as big in absolute value as the first one. Otherwise, there would be less investment in human capital in the first period. So the left-hand side of (11) will always be positive. The right-hand side of the inequality describes the option value effect of waiting. The first term measures the expected regret if migration takes place in period 1. Personal characteristics that increase wages or non-monetary utility of living in the source 
country (in Israel) increase (decrease) the amount of loss in case the decision to migrate in the first period turns out to be wrong ex-post. The amount of the loss in that case is weighted by the probability that this loss occurs. The second term reflects the fact that, in case the decision is procrastinated to the second period, knowledge of the realization of the period 2 shocks can be taken into account for the decision. The last term discounts migration costs.

The higher the wage effect compared to the option value effect, the more likely it is that migration will take place in the first period.

\subsection{The influence of human capital on the timing of migration}

To investigate the influence of source country human capital on the timing of the migration decision, we define $\mathrm{D}\left(\mathrm{s}^{\mathrm{S}}\right)$ as the difference between the right-hand side and the left-hand side of (11). The bigger $\mathrm{D}\left(\mathrm{s}^{\mathrm{S}}\right)$, the more people are expected to come in the first period.

$$
\begin{aligned}
& \mathrm{D}\left(\mathrm{s}^{\mathrm{S}}\right)=\left[\Delta \mathrm{w}_{1}-\Delta \mathrm{w}_{2,2}\right]+\beta\left[\Delta \mathrm{w}_{2,1}-\Delta \mathrm{w}_{2,2}\right] \\
& -\beta \Phi(\mathrm{z})\left[\Delta \mathrm{w}_{2,2}+\Delta \mathrm{b}_{2}\right]+\beta \sigma \phi(\mathrm{z})-\beta[1-\Phi(\mathrm{z})] \mathrm{c}
\end{aligned}
$$

We are interested in how this function depends on $s$. If the first derivative with respect to $\mathrm{s}^{\mathrm{S}}$ is positive, this means that people coming in the first period have more schooling than people coming in the second period. However, the sign of the derivative turns out to be ambiguous.

$$
\begin{aligned}
\partial \mathrm{D} / \partial \mathrm{s}^{\mathrm{s}} & =\beta\left(1-\mathrm{h}_{1}{ }^{\left.\mathrm{w}^{*}\right)}\right) \cdot \mathrm{k}^{\prime}(\cdot) \cdot \mathrm{g}^{\prime}\left(\mathrm{s}^{\mathrm{s}}\right) \\
& -[1-\beta \Phi(\mathrm{z})] \partial \mathrm{w}^{\mathrm{s}} / \partial \mathrm{s}^{\mathrm{s}}+\beta \phi(\mathrm{z})\left[\Delta \mathrm{w}_{2,2}+\Delta \mathrm{b}_{2}-\mathrm{c}\right] / \sigma-\beta \phi^{\prime}(\mathrm{z})
\end{aligned}
$$

There are four terms influencing the likelihood to migrate earlier. The first one comes from the wage effect; it is positive. The impact of the wage effect increases with the amount of source country human capital a person has, because the marginal return on the investment of new human capital per unit of time increases with the amount of source country human capital that is used in the production process. The three terms in the second line of (12) describe the impact through the option value effect. The second term is negative, the third and the fourth term can be positive or negative, depending on the sign of z. Notice the separability of the two kinds of effects: The first effect is only due to the dependency of Israeli wages on skills, whereas the effects in the second line are only due to the dependency of source country wages on skills. 
As the overall effect of human capital on the timing decision is ambiguous, it remains an empirical issue to show which effect dominates.

\subsection{Empirical Implementation}

In the last two paragraphs, I presented a hypothesis of how potential migrants decide when to come. One prediction of the model is that, because of the option value effect, people who, ceteris paribus, have a higher utility of staying in Israel or a lower utility of staying in the source country should come earlier.

Concerning the effect of education, however, the prediction of the model is ambiguous. If the model describes the timing of the migration decision accurately, the sign of the education coefficient shows which effect dominates. But we would also like to test whether the story the model tells makes sense. The fact that we observe that the more educated immigrants came earlier might be due to other reasons. For example, the more educated might have different information about the possibilities of migration. They might rely relatively more on written information than on reports of other people who migrated earlier. Moreover, they might live in bigger towns, where it is easier to gather information and to apply for a visa. In both cases, they may get quicker access to information about immigration than less educated potential migrants, which makes them come earlier.

Therefore, I will present three tests that support the explanation of the model as opposed to the explanations just given. The common idea of all three is, that if it is wage growth in Israel, and not inherent characteristics of more educated people that makes them come earlier, the effect should only hold among the working force of the immigrants. In addition, notice that among the working force itself, the impact of education should be stronger for younger persons. The younger someone is, the longer he profits from the returns to investments in education. Hence, if we have a positive coefficient for education, which means that the wage effect dominates the option value effect, we also expect an interaction term of age and education in the estimation to be negative, because human capital investment loses importance the older an individual is. ${ }^{7}$ Thus, the sign of the coefficient for the age-education interaction term is the first test. The second test will be to investigate the coefficient for education in a regression including only retired people. The inherent characteristics of a person who

\footnotetext{
${ }^{7}$ A similar idea has been used by Schwarz (1976). He uses the interaction between age and education in the likelihood to migrate to test an application of human capital theory.
} 
is more educated do not change with retirement, so if the education coefficient is insignificant for this sample, this is a hint that it is not living in a city or differences in the access to information that makes the more educated come earlier, but the effect on wage growth. A third test will be to compare the education coefficients for women with and without children. Having children decreases the probability of participation in the labor market, so the wage effect should be less important for mothers than for non-mothers.

In the model, shifts in the difference in utility in the two countries are covered by changes in $\Delta \varepsilon$. We would like to incorporate this in the estimation with variables describing changes in the individuals' life during the time spent in the country of origin, e.g. whether relatives already migrated, wages, or employment status. However, this information is not available. Therefore, changes in economic conditions are proxied by macroeconomic time series variables of Israel, the countries of origin, and the USA. Information on the USA is included to reflect the fact that the outside option for many immigrants is not only to stay in their country of origin, but also to go to the USA instead of Israel. Changes for the better in the source country and in the USA are expected to mitigate the likelihood of migration, whereas improvements of economic conditions in Israel are expected to increase the likelihood of immigration.

\section{Data}

The individual data I use in this paper are from the 1995 demographic Census of Israel and from the 1995-1998 samples of the demographic Labor Force Survey (LFS) of Israel. From these two data sets I selected all individuals who immigrated to Israel from countries of the FSU and six other Eastern European countries ${ }^{8}$ since 1989. ${ }^{9}$ The Census includes detailed information about $20 \%$ of the Israeli population in 1995. Therefore, I have data on $20 \%$ of all immigrants from the FSU and the Eastern European countries. Excluding children that were under 15 in 1995, I end up with around 90,000 observations.

The Labor Force Survey (LFS) is a yearly data set containing information for approximately 12,000 Israeli households. As it is on the characteristics of the Israeli Labor Force, there is no information about persons under the age of 15, and persons

\footnotetext{
${ }^{8}$ These countries are Romania, Bulgaria, Poland, Slovakia, the Czech Republic and Hungary.

${ }^{9}$ I also include Israeli-born offspring.
} 
aged more than 75 (in the 1995 sample) or more than 85 (in the succeeding years) are reported as being 75 or 85 , respectively. Combining the LFS data sets for the years 1995 to 1998 , I end up with around 20,000 observations. The main advantage, compared to the Census, is that it includes some observations of immigrants who came during the years 1996-1998, which extends the range of my dependent variable. However, immigrants arriving after 1995 are underrepresented in this data, and more so the later they came, because in every year, the LFS has only observations of immigrants up to that year. Therefore, observations for 1996 immigrants enter with double weight in the estimations, observations for 1997 enter with triple weight, and observations for 1998 with quadruple weight. Table 1 presents the number of observations for every year and the total number of immigrants from the FSU. After the weighting, the distribution of immigrants over the years reflects the population distribution fairly well.

Table 2 presents some summary statistics for the two data sets. Note that with more than 13 years of schooling on average, the immigrants have slightly more schooling than native Israelis. About $85 \%$ of all immigrants come from only five different source countries out of twenty.

The focus of this paper is on the changes in the observable characteristics of newly arriving immigrants over time. Figure 1 shows the development of the average age of immigrants who were between 25 and 60 years old in 1989, separate for all immigrants, for immigrants from the Ukraine, and for immigrants from Russia. There is no clear pattern, and differences between the graph for the Ukraine and for Russia are large. Figure 2 shows the development of average years of schooling for the same three groups. Immigrants from the Ukraine, and even more so those from Russia, generally have a higher level of education than the other immigrants. However, the downward trend is the same for all groups depicted. Hence, the decline in education seems not to be due to a change in the composition of the countries of origin.

The data on GDP growth and unemployment in Israel is calculated using official data from the Israeli Central Bureau of Statistics. GDP growth rates in the source countries and the data on the USA are from the EIU (Economics Intelligence Union), the research department of the Economist. 


\section{Estimation Methods and Econometric Issues}

The data introduced in the last section are used to see in which way observable characteristics influence the timing of migration. In particular, we want to see if more educated people migrate earlier. We use duration in the country of origin as the dependent variable and estimate both a continuous and a discrete failure time model.

Table 1 shows that the number of immigrants peaked in 1990 and 1991 and subsequently levels off at a roughly constant number of immigrants per year. This pattern is not reflected in the time series behavior of education over time, where, except for 1989, a continuous decline is observed (cf. figure 2). The same holds true for other explanatory variables like being Jewish, being married, or the number of children (not reported in the paper). It seems that the baseline hazard of migration varies strongly over time, whereas the coefficients for the explanatory variables are timeinvariant. This suggests a Cox proportional hazards model (Cox, 1972). The hazard is assumed to be

$$
\lambda(\mathrm{t} ; \mathrm{x}(\mathrm{t}))=\cdot \exp (\mathrm{x}(\mathrm{t}) \beta) \lambda_{0}(\mathrm{t}),
$$

where $\beta$ is the vector of unknown parameters and $\lambda_{0}(\mathrm{t})$ is the baseline hazard. The baseline hazard is an unknown function giving the hazard for $\mathrm{x}=0$, which is allowed to vary arbitrarily over time. Covariates also may vary over time. If there are no ties in the data, the partial likelihood function is given by

$$
L(\beta)=\prod_{j=1}^{k}\left[\frac{\exp \left[\mathrm{x}_{(\mathrm{j})}\left(\mathrm{t}_{(\mathrm{j})}\right) \beta\right]}{\sum_{\mathrm{l} \in \mathrm{R}\left(\mathrm{t}_{(\mathrm{j})}\right)} \exp \left[\mathrm{x}_{1}\left(\mathrm{t}_{(\mathrm{j})}\right) \beta\right]}\right]
$$

where $\mathrm{k}$ is the number of failure times with $\mathrm{t}_{(1)}<\mathrm{t}_{(2)}<\ldots<\mathrm{t}_{(\mathrm{k})}, \mathrm{x}_{(\mathrm{j})}\left(\mathrm{t}_{(\mathrm{j})}\right)$ is the value of $\mathrm{x}(\mathrm{t})$ for the item failing at $\mathrm{t}(\mathrm{j}), \mathrm{x}_{1}\left(\mathrm{t}_{\mathrm{j})}\right)$ is the value for the $l$ th item at the sample elapsed time $t$, and $R\left(t_{(j)}\right)$ is the set of individuals at risk at time $t_{(j)}$. The fact that the explanatory variable is on a yearly basis, however, leads to a large number of ties, i.e. many "failures" happen at the same time. Assuming that every failure in a given year is the first to fail (Breslow approximation) gives a crude approximation, which can seriously distort results if the number of ties is large.

Therefore, we also estimate a discrete time hazard model. The data is arranged in person-year form. Every person in every year up to the year in which migration takes place is considered one observation, which results in an artificial, unbalanced panel. The dependent variable, whether migration takes place for a certain observa- 
tion, is binary, which suggests estimation of a logit model. ${ }^{10}$ Time dummies fulfill the task of the baseline hazard in the continuous model. However, my data set has a serious drawback for this kind of estimation. Namely, as the data is Israeli data, it includes only persons that actually migrated until 1995 or 1998, respectively, so that the data is choice-based. There are no observations for people who migrated to another country or who have been remaining in the FSU so far. The estimated coefficients can only be interpreted as conditional on the fact that somebody left for Israel up to a certain time. In addition to that, the data is not censored as usually the case with duration data. In my sample, everybody who enters the last period is sure to fail, so that inclusion of yearly time dummies leads to collinearity. In addition to the reference year, the time dummy for the last year also has to be omitted. Another possibility to cover time effects is to include a polynomial of time in the regression.

Two problems are associated with the coefficients of the macroeconomic variables. These variables turn out to be highly significant in many cases, especially if there are no time effects included. However, first, macroeconomic variables for Israel and the USA, which are the same for all individuals, are likely to absorb some of the time effects. Analogously, the coefficient for GDP growth in the source countries may also include common unobservable characteristics of individuals from the respective source countries (Moulton, 1990). Second, the number of degrees of freedom used for the calculation of the standard errors is the number of individuals in the sample, whereas the number of different observations is restricted to the number of countries times the number of years (Card, 1995). A regression of the probability to migrate on the cell means of the individual characteristics and the macroeconomic variables delivers more realistic values for the standard errors. In this case, the coefficients are not significant.

\footnotetext{
${ }^{10}$ The model I estimate is very similar to a random effects probit with an unbalanced panel. Apart from the different assumption about the distribution of the dependent variable, the random effects probit allows for individual heterogeneity. In this case, however, individual heterogeneity does not seem to be important. I estimated the model as a random effects probit, and the estimated within-group correlation is rather low and the coefficients hardly change compared to a probit estimation that does not allow for individual heterogeneity.
} 


\section{$\underline{6 . \text { Estimation results }}$}

\section{$\underline{6.1 \text { General results }}$}

Estimations are made using the Census and the Labor Force Survey, including immigrants who were between 25 and 60 in 1989 and did not study at survey time. ${ }^{11}$

The results of the Cox proportionate hazard model are reported in table 4 . The first column reports results of an estimation with the Census, including dummies for Europe or a south-eastern country of the FSU as country of origin ${ }^{12}$. The second column replaces the two region dummies by dummies for every country of origin. Columns 3 and 4 repeat the estimations with the Labor Force Survey.

The dummy that is equal to one if the immigrant is not from the FSU, but from one of the six East European countries is expected to have a positive coefficient, because the possibility to emigrate arouse slightly earlier in these countries. In contrast to that, the dummy for the south-eastern countries of the FSU is expected to have a negative coefficient. The south-eastern countries of the FSU are relatively less developed than the other areas of the FSU, therefore migration is likely to be more complicated to organize. In addition to that, only in recent years, when the flow of FSU immigrants started to decrease, did the Jewish Agency for Israel (JAFI) place big immigration campaigns in these countries. Using dummies for every country of origin instead of these two regions only does not change the results. Therefore, in the discrete case only estimations with the two region dummies are reported. The logit estimations are presented in table 5. For both the Census and the Labor Force Survey, there are three different specifications to cover the time effect. The specification in the first and the fourth column is closest to the continuous case. The baseline hazard is replaced by yearly time dummy variables, with the last year omitted and the last but one year as the dummy reference group. The second and fifth column presents a specification with a third order polynomial of time and two macroeconomic variables. Results hardly differ. Finally, the estimation in the third and sixth column records a specification with two more macroeconomic variables, but without any time effect. Time effects are hidden in the macroeconomic variables. Although the macroeconomic variables in

\footnotetext{
${ }^{11}$ The data sets contain only information about the immigrants' characteristics at the date of the survey, whereas the model is about the immigrants' characteristics at the date of migration. If characteristics change in Israel because of being in Israel for a certain amount of time, there is an endogeneity problem. Therefore, people that are still studying in Israel are excluded, because the decision about the duration of education might be different in Israel than in the source country.

${ }^{12}$ The countries are Armenia, Azerbaijan, Georgia, Kazakhstan, Kurdistan, Tajikistan, Turkmenistan, and Uzbekistan.
} 
this specification all have the right sign and are highly significant, the size of the parameters is quite implausible. Problems concerning the reported standard errors of these variables were discussed in the previous section.

The coefficient for education, measured as years of schooling, is positive. More educated people migrate earlier. In terms of the model, the wage effect clearly dominates the option value effect. In the Census, older people come earlier, but this effect diminishes with age. The interaction variable of age with education is negative. This is the first of the three tests mentioned in section 3.4 to see if it is really due to human capital investment considerations and not for other reasons that the more educated are migrating earlier. Human capital considerations lose importance for older people, so, according to the theory, the interaction term is expected to be negative. The second and third test will be reported in section 6.2.

Being Jewish has a strong positive impact on the time of immigration. ${ }^{13}$ Assuming that the non-monetary utility $\mathrm{b}$ of living in Israel is higher for Jewish than for Non-Jewish persons, this reflects the option value effect. The higher the utility of living in Israel, the earlier migration is expected to take place. However, there might also be some other reasons that play a role here. First, Jewish people might come earlier because they have better information about the options of migration to Israel, or because they are more inclined to migrate to Israel than to any other country. So they do not wait to see how the options of going somewhere else turn out to be. Second, applicants who are themselves Jewish probably get their permission to make aliya (i.e. to migrate to Israel) quicker than people who are not Jewish and have to prove that they are of Jewish origin. And finally, if some Non-Jewish immigrants decide to convert to Judaism after having spent some time in Israel, the percentage of Jewish people in the data set is higher among immigrants who came earlier.

Being married increases the probability of migrating early. Eckstein and Weiss (1999) found a strong positive wage effect of being married for FSU immigrants in Israel. Without having an explanation for this effect, my result nevertheless is consistent with their finding. If the return to being married in Israel is higher than in the FSU, the wage gap is bigger for couples so that they are more likely to come than singles. Concerning children, results are mixed: In general, children delay migration.

\footnotetext{
${ }^{13}$ Jewish people in the data set are Jewish themselves. The Non-Jewish are those that immigrate as spouses or descendants of Jews.
} 
However, in the Labor Force Survey the hazard of migration increases in the number of children.

The results for the estimations with the Census and the Labor Force Survey differ only slightly. The main differences are in the coefficients for age, for the number of children, and for the region dummies. Concerning age, results are not very robust to different specifications anyway. The distribution for the "number of children" variable is extremely skewed in both samples. In addition to that, the variable is not measured correctly in the Labor Force Survey. The Survey has only information about the number of kids of age less than 15 in the year of the survey. I merge four different survey years without correcting for that. Concerning the region dummies, the number of observations is very low for some years in the Labor Force Survey. Census results are therefore likely to be more reliable in that respect.

\section{$\underline{6.2}$ The role of education for people out of the labor force}

In section 3.4, we discussed three informal tests to find evidence for the relevance of the human capital investment model to explain the decline in immigrants' education over time. The first test was presented in the last section: With increasing age, the impact of education on the timing of migration decreases. In this section, we check if the education coefficient for people out of the labor force differs from the coefficient for the working population. First, we look at a sample of retired people and compare the education coefficient in this sample with the coefficient for the working population. Second, we look at a sample of couples and compare the education coefficient of wives with and without children. In both cases, only Census estimations are reported. In the Labor Force Survey, the age variable is right-censored, and there is only poor information about family status. Therefore it is not suitable for this kind of analysis.

Table 6 repeats the estimation reported in the second column of table 5, but using the sample of immigrants who were at least 60 years old in 1989. To make comparison easier, the respective estimation from table 5 is repeated in the second column. The third column reports the estimation with a Census sample of couples, married at least since 1989, who migrated together.

If educated people have a different migration behavior because of different underlying characteristics or because their access to information is different, this should hold for all age groups. However, human capital investment considerations are 
no more relevant after retirement. ${ }^{14}$ In fact, the estimated coefficients for being Jewish, being married and for region of origin are roughly the same for the group aged $60+$ and the group aged between 25 and 60 . However, the education coefficient is not significant for the group aged $60+$, and the hypothesis that the coefficient for education is equal to the coefficient in the 25-60 group can be rejected at any common significance level. ${ }^{15}$ This is the second of the three tests discussed in section 3.4 to see whether the human capital investment story is reasonable.

The third test compares the impact of education for married women with and without children. In the estimation for couples in the last column in table 6 , the education coefficient for wives is interacted with a dummy for the couple having children aged between 0 and 12 in 1995 . The coefficient for wives without children is positive and significant. The hypothesis that it is equal to the coefficient of the husband cannot be rejected. In contrast to that, the coefficient of the wives with children is not significant, and the hypothesis that it is equal to the coefficient for wives without children has to be rejected.

The other results are similar to the results in the estimations with individuals. Not surprisingly, both spouses being Jewish has a big positive impact; and the effect of only one partner being Jewish is still positive and significant, but smaller. ${ }^{16}$

\subsection{Migration and wage assimilation of couples}

The fact that the estimated impact of education on the migration decision is the same for men and women if the couple has no children is an interesting feature of this immigration wave. It suggests that the family investment hypothesis does not apply in this case. In a nutshell, the family investment hypothesis states that upon arrival in the new country, it is the husband who invests in human capital, whereas the wife starts to work right from the beginning to earn a living for the family. ${ }^{17}$

It seems, however, that the labor market assimilation for FSU immigrant couples is much more symmetric than the family investment hypothesis suggests, and if there are any gender differences in labor market characteristics, they are rather in the

\footnotetext{
${ }^{14}$ Immigrants who immigrate to Israel after retirement get a pension (Bituach Leumi), which is independent of their educational level and of their former earnings in the source country.

${ }^{15}$ The insignificance of the education coefficient of the old age sample is not due to less variation in the dependent variable.

${ }^{16}$ In the sample, in $73 \%$ of the couples both spouses are Jewish, $23 \%$ of the couples are mixed, and $4 \%$ are both Non-Jewish.

${ }^{17}$ For Canada, see Baker and Benjamin (1997), for the USA, see Duleep and Sanders (1993).
} 
opposite direction. This is in line with the literature. Cohen (2000), using a data set with detailed information about the labor market history of FSU immigrants, finds that the unemployment rate for women in this sample is about $50 \%$ higher than the respective rate for men, and participation in training programs is slightly higher. However, the family investment hypothesis predicts that this is the other way round. One reason for the more symmetric behavior of couples might be that in this immigration wave, usually both spouses have the same amount of schooling, and the differences in schooling between the spouses are symmetrically distributed. The main argument against a family investment hypothesis in Israel, however, is that living expenses during participation in the training program are part of the absorption basket every new immigrant in Israel is entitled to get, so that the household budget constraint does not exclude the possibility that both partners participate in training.

\section{Conclusions}

This paper presents a simple model to explain the influence of the educational level on the timing of migration. Immigrants with a higher level of education have an incentive to come earlier, because they need time in the new country to make their imported human capital usable on the new labor market. On the other hand, their initial wage decrease is higher than the decrease for unskilled immigrants. Although the theoretical effect is ambiguous, the estimations clearly suggest that the investment effect for human capital dominates the initial earnings loss. Other empirical findings are that being Jewish, being married, and having no children encourage early migration. Changes in macroeconomic conditions are not able to explain changes in the number of immigrants over time.

\section{$\underline{\text { 8. Literature }}$}

American Jewish Yearbook (1990-1999): Report about the Federal Republic of Germany, volumes 90-99, edited by David Singer.

Baker, Michael and Dwayne Benjamin (1997): The Role of the Family in Immigrants' Labor Market Activity: An Evaluation of Alternative Explanations, American Economic Review 87(4), 705-727.

Bauer, Thomas and Klaus F. Zimmermann (1998): Causes of International Migration: A Survey, in: Gorter, Cees, Peter Nijkamp and Jacques Poot (eds.), "Crossing borders. Regional and Urban Perspectives on International Migration", Ashgate Publishing Ltd, Aldershot et al., 95-127. 
Borjas, George J. (1985): Assimilation, Changes in Cohort Quality, and the Earnings of Immigrants, Journal of Labor Economics 3(4), 463-489.

--- (1995): Assimilation and Changes in Cohort Quality Revisited: What Happened to Immigrant Earnings in the 1980s? Journal of Labor Economics 13(2), 201-245.

Burda, Michael (1995): Migration and the Option Value of Waiting, Economic and Social Review 27(1), 1-19.

Card, David (1995): The Wage Curve: A Review, Journal of Economic Literature 33, 785-799.

Chiswick, Barry R., Yinon Cohen and Tzippi Zach (1997): The Labor Market Status of Immigrants: Effects of the Unemployment Rate at Arrival and Duration of Residence, Industrial and Labor Relations Review 50(2), 289-303.

Cohen, Sarit (2000): Training and Work Experience Effects on Labor Market Absorption of Female Immigrants, Tel Aviv University, The Eitan Berglas School of Economics.

Cox, David R. (1972): Regression models and life tables. Journal of the Royal Statistical Society, Series B 34, 187-220.

Duleep, Harriet Orcutt and Mark C. Regets (1999): Immigrants and Human-Capital Investment, American Economic Association Papers and Proceedings 89(2), 186-191.

Duleep, Harriet Orcutt and Seth Sanders (1993): The Decision to Work by Married Immigrant Women, Industrial and Labor Relations Review 46(4), 67-80.

Eckstein, Zvi and Yoram Weiss (1998): The Absorption of Highly Skilled Immigrants: Israel, 1990-1995, Foerder Institute Working Paper 3-98.

--- (1999): The Integration of Immigrants from the Former Soviet Union in the Israeli Labor Market, Foerder Institute Working Paper 33-99.

Friedberg, Rachel M. (2000): You can't take it with you? Immigrant Assimilation and the Portability of Human Capital, Journal of Labor Economics 18 (2), 221-251.

Gitelman, Zvi (1997): "From a Northern Country": Russian and Soviet Jewish Immigration to America and Israel in Historical Perspective, in: Russian Jews on Three Continents, edited by Noah Lewin-Epstein, Yaacov Ro'i and Paul Ritterband, London.

Hatton, Timothy (1995): A Model of U.K. Emigration, 1870-1913, The Review of Economics and Statistics 77(3), 407-415.

Moulton, Brent R. (1990): An Illustration of a Pitfall in Estimating the Effects of Aggregate variables on Micro Units, The Review of Economics and Statistics 72(2), 334338.

O'Connell, Paul G.J. (1997): Migration under Uncertainty: "Try your luck" or "Wait and see", Journal of Regional Science 37(2), 331-374.

Pindyck, Robert (1991): Irreversibility, Uncertainty and Investment, Journal of Economic Literature 29, 1110-1148.

Schwartz, Aba (1976): Migration, Age, and Education, Journal of Political Economy 84, 701-719. 
Tolts, Mark (1999): Demography of the Jews in the Former Soviet Union: Yesterday and Today, unpublished working paper of the Avraham Harman Institute of Contemporary Jewry, The Hebrew University of Jerusalem.

Weiss, Yoram, and Robert J. Willis (1997): Match Quality, New Information, and Marital Dissolution, Journal of Labor Economics 15(1), S293-S329. 
$\underline{\text { Tables and Figures }}$

Table 1: Number of immigrants per year (in thousands)

\begin{tabular}{|c|cccccccccc|}
\hline Year & 1989 & 1990 & 1991 & 1992 & 1993 & 1994 & 1995 & 1996 & 1997 & 1998 \\
\hline Census & 2.3 & 27.7 & 21.5 & 9.8 & 9.5 & 9.7 & 7.3 & & & \\
LFS & 0.5 & 5.1 & 4.3 & 1.8 & 1.9 & 2.0 & 1.8 & 2.5 & 2.1 & 0.7 \\
Total & 12.9 & 176.5 & 140.2 & 61.2 & 64.2 & 64.5 & 61.2 & 59.2 & 55.6 & 47.0 \\
\hline
\end{tabular}

Note: Total is total number of immigrants from the FSU, data from the Israeli Central Bureau of Statistics

Table 2: Summary statistics

\begin{tabular}{|l|l|l|}
\hline & Census & $\begin{array}{l}\text { Labor Force Survey } \\
1995-1998\end{array}$ \\
\hline Total number of observations & 87,931 & 19,536 \\
\hline $\begin{array}{l}\text { Avg. education (years of schooling) for } \\
\text { people between 25 and 60 in 1989 }\end{array}$ & 13.39 & 13.76 \\
\hline Percentage married* & 57.03 & 59.78 \\
\hline Percentage Jewish & 89.75 & 93.76 \\
\hline $\begin{array}{l}\text { Percentages coming from the five } \\
\text { countries with the most immigrants**18 }\end{array}$ & $\begin{array}{l}\text { Ukraine 34.77 } \\
\text { Russia 33.48 } \\
\text { Belarus 7.49 } \\
\text { Uzbekistan 6.12 } \\
\text { Moldova 5.12 }\end{array}$ & $\begin{array}{l}\text { Ukraine 33.29 } \\
\text { Russia 29.91 } \\
\text { Belarus 8.01 } \\
\text { Uzbekistan 7.84 } \\
\text { Moldova 5.34 }\end{array}$ \\
\hline
\end{tabular}

Note: *for the Census married since 1989 at least, ** percentages are given excluding "Soviet Union" as an answer

\footnotetext{
${ }^{18}$ The information in the data set is not "country of origin", but "country of birth", and I take them as being the same. I do not consider that as a problem because a dummy for persons with younger family members that were born in a different country than they themselves proved to be insignificant.
} 
Table 3: Maximum and minimum GDP growth rates of the countries of origin (EIU data)

\begin{tabular}{|c|c|c|c|c|}
\hline Year & Minimum & Country & Maximum & Country \\
\hline 1989 & -7 & Turkmenistan & 8.8 & Moldova \\
\hline 1990 & -12 & Poland & 11.3 & Uzbekistan \\
\hline 1991 & -20.6 & Georgia & -.5 & Uzbekistan \\
\hline 1992 & -52.4 & Armenia & 2.6 & Poland \\
\hline 1993 & -29.3 & Georgia & 3.8 & Poland \\
\hline 1994 & -30.9 & Moldova & 5.4 & Armenia \\
\hline 1995 & -12.4 & Tajikistan & 7.2 & Romania \\
\hline 1996 & -10.1 & Bulgaria & 11.4 & Georgia \\
\hline 1997 & -25.9 & Turkmenistan & 11.4 & Estonia \\
\hline 1998 & -7 & Moldova & 7 & Belarus \\
\hline
\end{tabular}


Table 4: Cox proportionate hazard model

\begin{tabular}{|c|c|c|c|c|}
\hline \multirow[b]{2}{*}{ Education } & \multicolumn{2}{|c|}{ Census (25-59) } & \multicolumn{2}{|c|}{ Labor Force Survey (25-59) } \\
\hline & $\begin{array}{l}0.053 * * * \\
(.005)\end{array}$ & $\begin{array}{l}0.054 * * * \\
(.005)\end{array}$ & $\begin{array}{l}0.090 * * * \\
\quad(.016)\end{array}$ & $\begin{array}{l}0.088 * * * \\
\quad(.016)\end{array}$ \\
\hline Age in 1989 & $\begin{array}{l}0.041 * * * \\
(.004)\end{array}$ & $\begin{array}{l}0.040 * * * \\
(.004)\end{array}$ & $\begin{array}{l}0.013 \\
(.013)\end{array}$ & $\begin{array}{l}0.012 \\
(.013)\end{array}$ \\
\hline $\begin{array}{l}\text { Age in } 1989 \\
\text { squared }\end{array}$ & $\begin{array}{c}-0.0005 * * * \\
(.00004)\end{array}$ & $\begin{array}{c}-0.0005 * * * \\
(.00004)\end{array}$ & $\begin{array}{l}0.00002 \\
(.00013)\end{array}$ & $\begin{array}{l}0.00014 \\
(.00019)\end{array}$ \\
\hline $\begin{array}{c}\text { Education * Age } \\
1989\end{array}$ & $\begin{array}{c}-0.0007 * * * \\
(.0001)\end{array}$ & $\begin{array}{c}-0.0007 * * * \\
(.0001)\end{array}$ & $\begin{array}{c}-0.0014 * * * \\
(.0004)\end{array}$ & $\begin{array}{c}-0.0013 * * * \\
(.0004)\end{array}$ \\
\hline Jewish & $\begin{array}{l}0.508 * * * \\
(.011)\end{array}$ & $\begin{array}{l}0.500 * * * \\
(.011)\end{array}$ & $\begin{array}{l}0.515 * * * \\
\quad(.034)\end{array}$ & $\begin{array}{l}0.512 * * * \\
\quad(.036)\end{array}$ \\
\hline Married & $\begin{array}{l}0.174 * * * \\
(.009)\end{array}$ & $\begin{array}{l}0.170 * * * \\
\quad(.009)\end{array}$ & $\begin{array}{l}0.148 * * * \\
\quad(.028)\end{array}$ & $\begin{array}{l}0.147 * * * \\
\quad(.028)\end{array}$ \\
\hline Child $\left(<15^{1}\right)$ & $\begin{array}{c}-0.041 * * * \\
(.015)\end{array}$ & $\begin{array}{c}-0.043 * * * \\
(.015)\end{array}$ & $\begin{array}{c}-0.132 * * * \\
(.045)\end{array}$ & $\begin{array}{c}-0.112 * * \\
(.045)\end{array}$ \\
\hline $\begin{array}{c}\text { Number of } \\
\text { Children }\left(<15^{1}\right)\end{array}$ & $\begin{array}{c}-0.015^{*} \\
(.008)\end{array}$ & $\begin{array}{c}-0.015^{*} \\
(.008)\end{array}$ & $\begin{array}{l}0.093 * * * \\
\quad(.025)\end{array}$ & $\begin{array}{l}0.075 * * * \\
(.026)\end{array}$ \\
\hline South-East & $\begin{array}{c}-0.178 * * * \\
(0.011)\end{array}$ & & $\begin{array}{l}-0.004 \\
(0.032)\end{array}$ & \\
\hline Europe & $\begin{array}{l}0.108 * * * \\
(0.031)\end{array}$ & & $\begin{array}{l}-0.100 \\
(0.086)\end{array}$ & \\
\hline $\begin{array}{l}\text { GDP growth rate } \\
\text { source country }\end{array}$ & $\begin{array}{c}0.003 * * * \\
(0.0007)\end{array}$ & $\begin{array}{l}-0.002 * * \\
(0.0009)\end{array}$ & $\begin{array}{c}0.005 * * \\
(0.002)\end{array}$ & $\begin{array}{l}-0.004 * \\
(0.002)\end{array}$ \\
\hline Country dummies & no & yes & No & yes \\
\hline Observations & 40,843 & 40,843 & 10,036 & 10,036 \\
\hline Wald chi2 & 3738.39 & 3738.39 & 361.13 & 440.41 \\
\hline Log likelihood & -403085.59 & -403085.59 & -99182.18 & -99111.01 \\
\hline
\end{tabular}

Note: robust standard errors in parentheses, ${ }^{* * *}$ sign. $1 \%, * *$ sign. $5 \%, *$ sign. $10 \%,{ }^{1)} 1995$ is reference year, for Labor Force Survey children younger than 15 in the survey year 
Table 5: Discrete time hazard model (logit)

\begin{tabular}{|c|c|c|c|c|c|c|}
\hline \multirow[b]{2}{*}{ Education } & \multicolumn{3}{|c|}{ Census (25-59) } & \multicolumn{3}{|c|}{ Labor Force Survey (25-59) } \\
\hline & $\begin{array}{l}0.095 * * * \\
(.008)\end{array}$ & $\begin{array}{l}0.096^{* * * *} \\
(.008)\end{array}$ & $\begin{array}{l}0.092 * * * \\
\quad(.008)\end{array}$ & $\begin{array}{c}0.135 * * * \\
(.023)\end{array}$ & $\begin{array}{c}0.134 * * * \\
\quad(.023)\end{array}$ & $\begin{array}{c}0.095 * * * \\
\quad(.014)\end{array}$ \\
\hline Age in 1989 & $\begin{array}{l}0.070 * * * \\
(.007)\end{array}$ & $\begin{array}{l}0.071 * * * \\
\quad(.007)\end{array}$ & $\begin{array}{l}0.068 * * * \\
(.007)\end{array}$ & $\begin{array}{l}0.021 \\
(.019)\end{array}$ & $\begin{array}{l}0.020 \\
(.019)\end{array}$ & $\begin{array}{l}0.021 * \\
(.011)\end{array}$ \\
\hline Age in 1989 sq & $\begin{array}{c}0.0008 * * * \\
(.00007)\end{array}$ & $\begin{array}{c}0.0008 * * * \\
(.00007)\end{array}$ & $\begin{array}{c}0.0008 * * * \\
(.00007)\end{array}$ & $\begin{array}{c}-0.00003 \\
(.0002)\end{array}$ & $\begin{array}{c}-0.00003 \\
(.0002)\end{array}$ & $\begin{array}{c}-0.00001 \\
(.0001)\end{array}$ \\
\hline $\begin{array}{c}\text { Education * Age } \\
1989\end{array}$ & $\begin{array}{c}-0.001 * * * \\
(.0001)\end{array}$ & $\begin{array}{c}-0.001 * * * \\
(.0001)\end{array}$ & $\begin{array}{c}-0.001 * * * \\
(.0002)\end{array}$ & $\begin{array}{c}-0.002 * * * \\
(.0005)\end{array}$ & $\begin{array}{c}-0.002 * * * \\
(.0005)\end{array}$ & $\begin{array}{c}-0.001 * * * \\
(.0003)\end{array}$ \\
\hline Jewish & $\begin{array}{c}0.833 * * * \\
(.017)\end{array}$ & $\begin{array}{l}0.890 * * * \\
(.020)\end{array}$ & $\begin{array}{l}0.854 * * * \\
(.020)\end{array}$ & $\begin{array}{c}0.762 * * * \\
(.056)\end{array}$ & $\begin{array}{c}0.762 * * * \\
(.058)\end{array}$ & $\begin{array}{l}0.565^{* * * *} \\
(.028)\end{array}$ \\
\hline Married & $\begin{array}{c}0.292 * * * \\
(.015)\end{array}$ & $\begin{array}{l}0.304 * * * \\
\quad(.015)\end{array}$ & $\begin{array}{l}0.294 * * * \\
\quad(.015)\end{array}$ & $\begin{array}{c}0.222 * * * \\
(.021)\end{array}$ & $\begin{array}{c}0.224 * * * \\
(.042)\end{array}$ & $\begin{array}{c}0.168 * * * \\
\quad(.024)\end{array}$ \\
\hline Child $\left(<15^{1}\right)$ & $\begin{array}{c}-0.071 * * * \\
(.024)\end{array}$ & $\begin{array}{c}-0.076 * * * \\
(.026)\end{array}$ & $\begin{array}{c}-0.073 * * * \\
(.024)\end{array}$ & $\begin{array}{c}-0.192 * * \\
(.066)\end{array}$ & $\begin{array}{c}-0.190 * * \\
(.066)\end{array}$ & $\begin{array}{c}-0.153 * * \\
(.040)\end{array}$ \\
\hline \# Children $\left(<15^{1}\right)$ & $\begin{array}{c}-0.025^{*} \\
(.014)\end{array}$ & $\begin{array}{c}-0.027 * \\
(.015)\end{array}$ & $\begin{array}{c}-0.025^{*} \\
(.014)\end{array}$ & $\begin{array}{c}0.132 * * * \\
(.036)\end{array}$ & $\begin{array}{l}0.131 * * * \\
\quad(.037)\end{array}$ & $\begin{array}{c}0.099 * * * \\
(.023)\end{array}$ \\
\hline South-East & $\begin{array}{c}-0.308 * * * \\
(0.017)\end{array}$ & $\begin{array}{c}-0.313 * * * \\
(0.018)\end{array}$ & $\begin{array}{c}-0.292 * * * \\
(0.018)\end{array}$ & $\begin{array}{c}0.006 \\
(0.046)\end{array}$ & $\begin{array}{c}0.001 \\
(0.047)\end{array}$ & $\begin{array}{c}0.024 \\
(0.028)\end{array}$ \\
\hline Europe & $\begin{array}{c}0.145 * * * \\
(0.055)\end{array}$ & $\begin{array}{c}0.189 * * * \\
(0.055)\end{array}$ & $\begin{array}{c}0.190 * * * \\
(0.052)\end{array}$ & $\begin{array}{l}-0.148 \\
(0.133)\end{array}$ & $\begin{array}{l}-0.171 \\
(0.137)\end{array}$ & $\begin{array}{l}-0.039 \\
(0.075)\end{array}$ \\
\hline $\begin{array}{l}\text { GDP growth rate } \\
\text { origin }\end{array}$ & $\begin{array}{l}0.018 * * * \\
(0.001)\end{array}$ & $\begin{array}{l}0.012 * * * \\
(0.001)\end{array}$ & $\begin{array}{c}0.010 * * * \\
(0.001)\end{array}$ & $\begin{array}{c}0.006 * * * \\
(0.002)\end{array}$ & $\begin{array}{l}0.010^{* * * *} \\
(0.002)\end{array}$ & $\begin{array}{c}-0.008 * * * \\
(0.002)\end{array}$ \\
\hline $\begin{array}{l}\text { GDP growth rate } \\
\text { Israel }\end{array}$ & & $\begin{array}{l}0.013 * * * \\
(0.004)\end{array}$ & $\begin{array}{c}0.479 * * * \\
(0.005)\end{array}$ & & $\begin{array}{c}0.008 \\
(0.008)\end{array}$ & $\begin{array}{c}0.042^{* * * *} \\
(0.009)\end{array}$ \\
\hline $\begin{array}{c}\text { Unemployment } \\
\text { Israel }\end{array}$ & & $\begin{array}{c}-0.204 * * * \\
(0.021)\end{array}$ & $\begin{array}{c}-1.049 * * * \\
(0.009)\end{array}$ & & $\begin{array}{c}-0.745 * * * \\
(0.027)\end{array}$ & $\begin{array}{c}-0.395 * * * \\
(0.017)\end{array}$ \\
\hline $\begin{array}{l}\text { GDP growth rate } \\
\text { USA }\end{array}$ & & & $\begin{array}{c}-0.728 * * * \\
(0.007)\end{array}$ & & & $\begin{array}{c}-0.204 * * * \\
(0.013\end{array}$ \\
\hline $\begin{array}{c}\text { Unemployment } \\
\text { USA }\end{array}$ & & & $\begin{array}{l}1.491 * * * \\
(0.016)\end{array}$ & & & $\begin{array}{c}0.201 * * * \\
(0.038)\end{array}$ \\
\hline $\begin{array}{l}\text { Time dummies 89- } \\
93\end{array}$ & yes & no & no & yes & no & no \\
\hline $\begin{array}{l}\text { Time polynomial } \\
\qquad\left(\mathrm{t}, \mathrm{t}^{2}, \mathrm{t}^{3}\right)\end{array}$ & no & yes & no & no & yes & no \\
\hline $\begin{array}{c}\text { Macroeconomic } \\
\text { variables }\end{array}$ & & for Israel & $\begin{array}{l}\text { for Israel } \\
\text { and USA }\end{array}$ & & for Israel & $\begin{array}{l}\text { for Israel } \\
\text { and USA }\end{array}$ \\
\hline Observations & 40,843 & 40,843 & 40,843 & 10,036 & 10,036 & 10,036 \\
\hline Wald chi2 & 20969.56 & 26599.08 & 29078.60 & 3056.80 & 2971.42 & 1452.35 \\
\hline Deviance & 140584 & 137858 & 140713 & 48158 & 48134 & 55150 \\
\hline
\end{tabular}

Note: robust standard errors in parentheses, *** sign. $1 \%$, ** sign. $5 \%$, *sign. $10 \%$, standard errors corrected for clustering on id, ${ }^{1)} 1995$ is reference year, for Labor Force Survey children younger than 15 in the survey year 
Table 6: Discrete time hazard model for immigrants 60+ and couples

\begin{tabular}{|c|c|c|c|c|}
\hline & \multicolumn{2}{|c|}{ Individuals } & \multirow{2}{*}{$\begin{array}{c}\text { Couples } \\
25-59\end{array}$} & \\
\hline Age group & $60+$ & $25-59$ & & \\
\hline Education & $0.002(.012)$ & $0.096 * * *(.008)$ & $\begin{array}{c}0.105 * * *(.023) \\
0.059 * *(.024) \\
-0.004(.004)\end{array}$ & $\begin{array}{l}\text { Educ. husband } \\
\text { Educ. wife no kid } \\
\text { Educ. wife kid }\end{array}$ \\
\hline Age in 1989 & $0.001(.003)$ & $0.071 * * *(.007)$ & $\begin{array}{c}0.059 * * *(.023) \\
-0.016(.023)\end{array}$ & $\begin{array}{c}\text { Age } 1989 \text { husband } \\
\text { Age } 1989 \text { wife }\end{array}$ \\
\hline Age in $1989 \mathrm{sq}$ & $0.0000(.00000)$ & $0.0008 * * *(.0001)$ & $\begin{array}{c}-0.0005 * *(.0003) \\
0.00004(.0003)\end{array}$ & $\begin{array}{l}\text { Age } 1989 \text { sq husb. } \\
\text { Age } 1989 \text { sq wife }\end{array}$ \\
\hline $\begin{array}{l}\text { Education * } \\
\text { Age } 1989\end{array}$ & $0.001(.0002)$ & $-0.001 * * *(.0001)$ & $\begin{array}{c}-0.002 * * *(.0005) \\
-0.0003(.0006)\end{array}$ & $\begin{array}{l}\text { Educ. * Age husb. } \\
\text { Educ. * Age wife }\end{array}$ \\
\hline Jewish & $0.658 * * *(.052)$ & $0.890 * * *(.020)$ & $\begin{array}{l}1.390 * * *(.080) \\
0.389 * * *(.081)\end{array}$ & $\begin{array}{c}\text { Both Jewish } \\
\text { One spouse Jewish }\end{array}$ \\
\hline Married & $0.122 * * *(.023)$ & $0.304 * * *(.015)$ & & \\
\hline Child $\left(<15^{1}\right)$ & $-0.115^{*}(.064)$ & $-0.076 * * *(.026)$ & $\begin{array}{l}-0.190 * * *(.037) \\
-0.173 * * *(.037)\end{array}$ & $\begin{array}{l}\text { Child }\left(0-6^{1}\right) \\
\text { Child }\left(7-15^{1}\right)\end{array}$ \\
\hline $\begin{array}{l}\text { \# Children } \\
\left(<15^{1}\right)\end{array}$ & $-0.017(.042)$ & $-0.027 *(.015)$ & $0.120 * * *(.023)$ & \# Children $\left(<15^{1}\right)$ \\
\hline South-East & $-0.295 * * *(.040)$ & $-0.313 * * *(.018)$ & $-0.331 * * *(.040)$ & South-East \\
\hline Europe & $0.109 *(.059)$ & $0.189 * * *(.055)$ & $0.815 * * *(.193)$ & Europe \\
\hline $\begin{array}{l}\text { GDP growth } \\
\text { rate origin }\end{array}$ & $0.004 *(.002)$ & $0.012 * * *(.001)$ & $0.010 * * *(.002)$ & $\begin{array}{l}\text { GDP growth rate } \\
\text { origin }\end{array}$ \\
\hline $\begin{array}{l}\text { GDP growth } \\
\text { rate Israel }\end{array}$ & $0.002(.007)$ & $0.013 * * *(.004)$ & $0.017 * * *(.044)$ & $\begin{array}{l}\text { GDP growth rate } \\
\text { Israel }\end{array}$ \\
\hline $\begin{array}{l}\text { Unemployment } \\
\text { Israel }\end{array}$ & $-0.162 * * *(.035)$ & $-0.204 * * *(.021)$ & $-0.252 * * *(.044)$ & $\begin{array}{c}\text { Unemployment } \\
\text { Israel }\end{array}$ \\
\hline Observations & 14,234 & 40,843 & 10,741 & Observations \\
\hline Wald chi2 & 9343.22 & 26599.08 & 6420.79 & Wald chi2 \\
\hline Deviance & 49629 & 137858 & 34072 & Deviance \\
\hline
\end{tabular}

Note: estimations include a time polynomial of order 3, robust standard errors in parentheses, $* * *$ sign. $1 \%$, ** sign. 5\%, *sign. 10\%, standard errors corrected for clustering on id, ${ }^{1)} 1995$ is reference year 


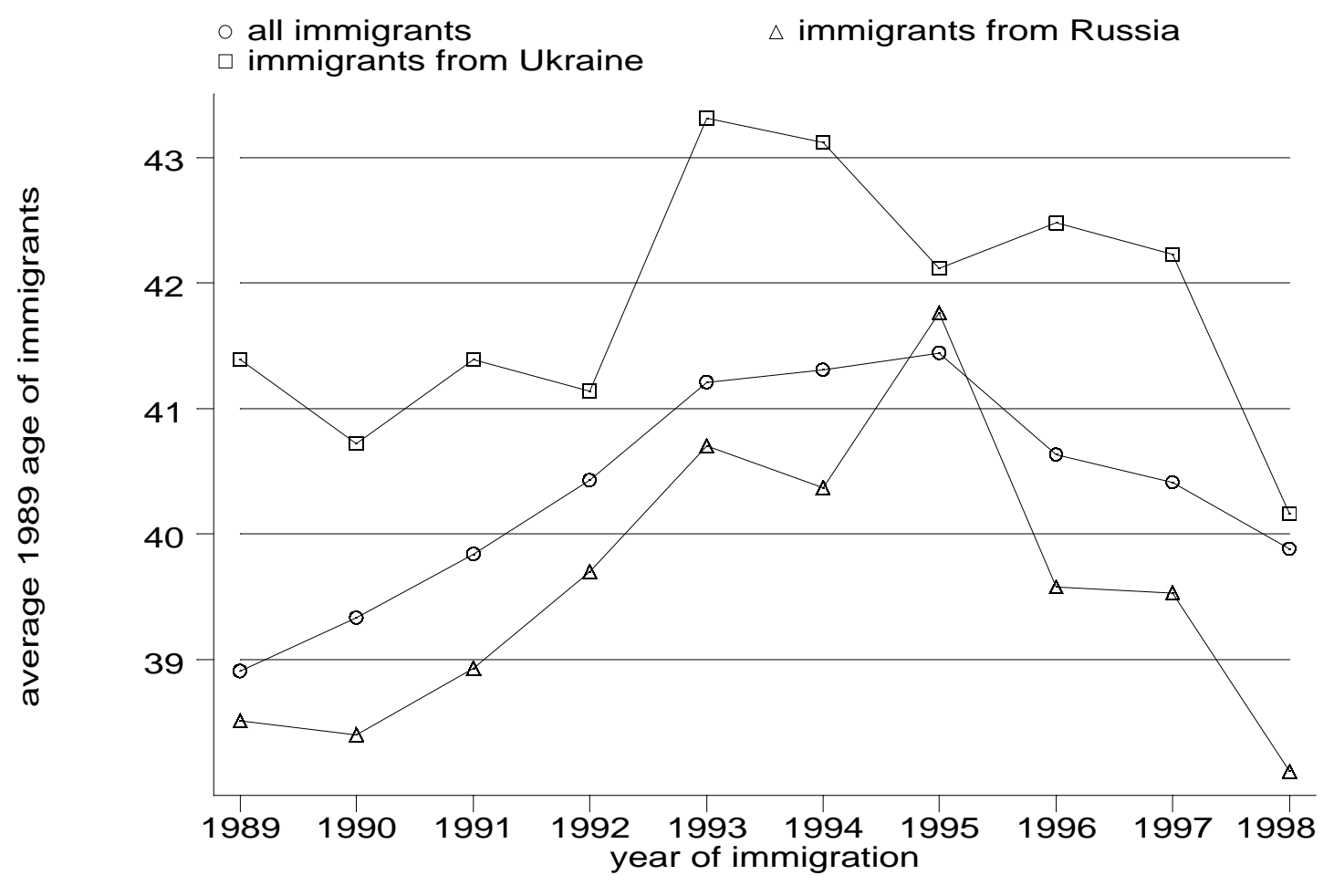

Figure 1: average age in 1989 for all immigrants, for immigrants from Russia, and for immigrants from the Ukraine (between 25 and 60 in 1989, data from the LFS 19951998) 


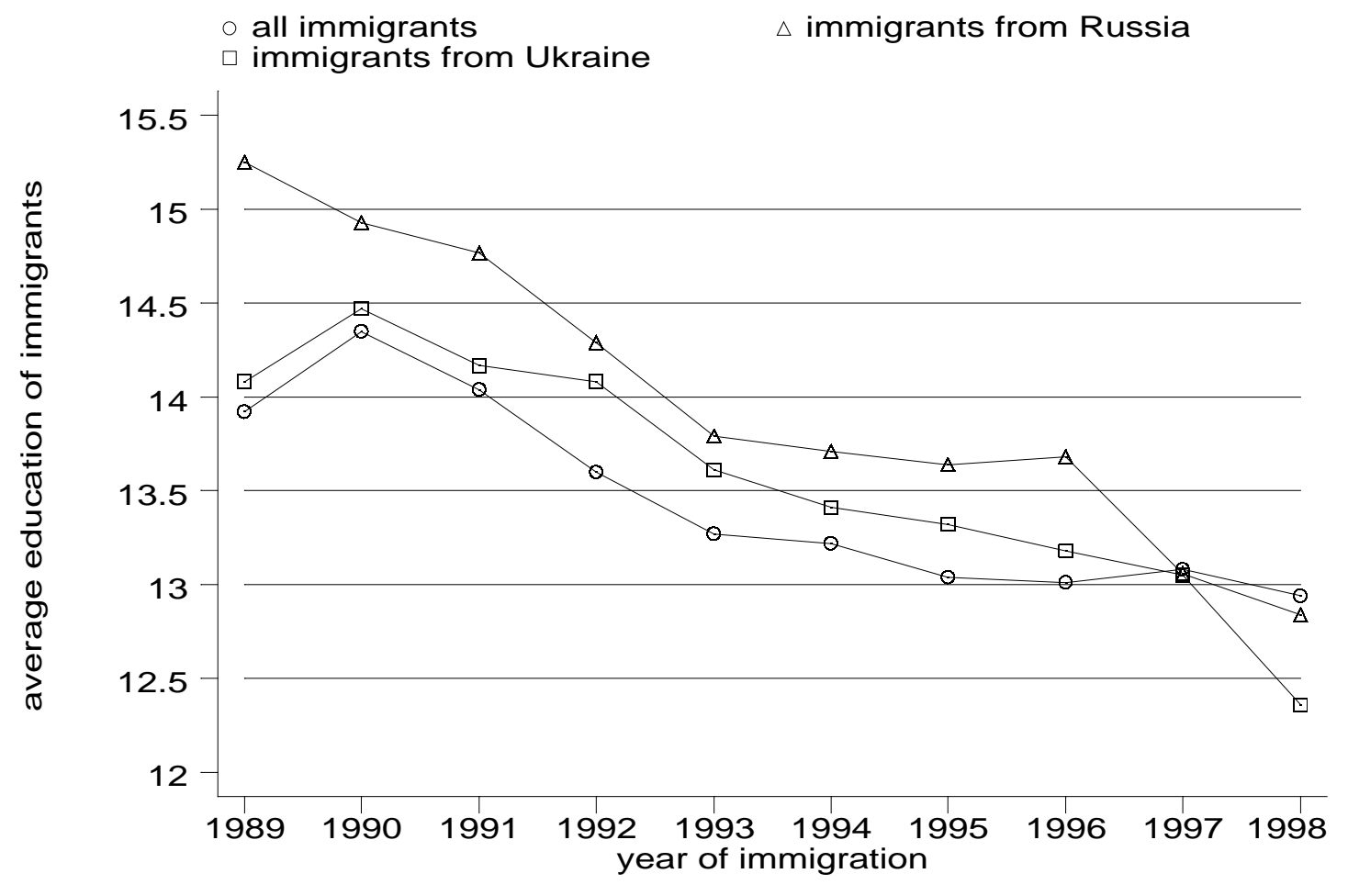

Figure 2: average education (years of schooling) for all immigrants, for immigrants from Russia, and for immigrants from the Ukraine (between 25 and 60 in 1989, data from the LFS 1995-1998) 


\section{IZA Discussion Papers}

No Author(s)

141 R. Hujer M. Wellner

142 J. J. Dolado

F. Felgueroso

J. F. Jimeno

143 P. J. Luke

M. E. Schaffer

144 G. Saint-Paul

145 M.-S. Yun

146 T. K. Bauer

J. P. Haisken-DeNew

147 M. Belot

J. C. van Ours

148 L. Goerke

149 R. Lalive

J. C. van Ours

J. Zweimüller

150 J. DiNardo

K. F. Hallock

J.-St. Pischke

151 M. Ward

152 J. J. Dolado

F. Felgueroso

J. F. Jimeno

153 A. S. Kalwij

M. Gregory

154 M. Gerfin

M. Lechner

155 J. Hansen
Titel

Area

Date

The Effects of Public Sector Sponsored Training on Individual Employment Performance in East Germany

Explaining Youth Labor Market Problems in Spain: 3 Crowding-Out, Institutions, or Technology Shifts?

Wage Determination in Russia: An Econometric 4 Investigation

$4 / 00$

Flexibility vs. Rigidity: Does Spain have the worst of 1 both Worlds?

Decomposition Analysis for a Binary Choice Model 7

$4 / 00$

Employer Learning and the Returns to Schooling 5

$4 / 00$

$4 / 00$

Does the Recent Success of Some OECD 3

3

Countries in Lowering their Unemployment Rates

Lie in the Clever Design of their Labour Market

Reforms?

Employment Effects of Labour Taxation in an Efficiency Wage Model with Alternative Budget Constraints and Time Horizons

The Impact of Active Labor Market Programs and Benefit Entitlement Rules on the Duration of Unemployment

Unions and the Labor Market for Managers

Gender, Salary and Promotion in the Academic 5 Profession

$5 / 00$

The Role of the Minimum Wage in the Welfare 3 State: An Appraisal

$5 / 00$

Overtime Hours in Great Britain over the Period 3 1975-1999: A Panel Data Analysis

Microeconometric Evaluation of the Active Labour 6 Market Policy in Switzerland

$5 / 00$

$5 / 00$

The Duration of Immigrants' Unemployment Spells: $\quad 1 / 3$ Evidence from Sweden 


\begin{tabular}{|c|c|c|c|c|}
\hline 156 & $\begin{array}{l}\text { C. Dustmann } \\
\text { F. Fabbri }\end{array}$ & $\begin{array}{l}\text { Language Proficiency and Labour Market Per- } \\
\text { formance of Immigrants in the UK }\end{array}$ & 1 & $5 / 00$ \\
\hline 157 & $\begin{array}{l}\text { P. Apps } \\
\text { R. Rees }\end{array}$ & $\begin{array}{l}\text { Household Production, Full Consumption and } \\
\text { the Costs of Children }\end{array}$ & 7 & $5 / 00$ \\
\hline 158 & $\begin{array}{l}\text { A. Björklund } \\
\text { T. Eriksson } \\
\text { M. Jäntti } \\
\text { O. Raaum } \\
\text { E. Österbacka }\end{array}$ & $\begin{array}{l}\text { Brother Correlations in Earnings in Denmark, } \\
\text { Finland, Norway and Sweden Compared to the } \\
\text { United States }\end{array}$ & 5 & $5 / 00$ \\
\hline 159 & $\begin{array}{l}\text { P.- J. Jost } \\
\text { M. Kräkel }\end{array}$ & Preemptive Behavior in Sequential Tournaments & 5 & $5 / 00$ \\
\hline 160 & M. Lofstrom & $\begin{array}{l}\text { A Comparison of the Human Capital and Signaling } \\
\text { Models: The Case of the Self-Employed and the } \\
\text { Increase in the Schooling Premium in the 1980's }\end{array}$ & 5 & $6 / 00$ \\
\hline 161 & $\begin{array}{l}\text { V. Gimpelson } \\
\text { D. Treisman } \\
\text { G. Monusova }\end{array}$ & $\begin{array}{l}\text { Public Employment and Redistributive Politics: } \\
\text { Evidence from Russia's Regions }\end{array}$ & 4 & $6 / 00$ \\
\hline 162 & $\begin{array}{l}\text { C. Dustmann } \\
\text { M. E. Rochina- } \\
\text { Barrachina }\end{array}$ & $\begin{array}{l}\text { Selection Correction in Panel Data Models: An } \\
\text { Application to Labour Supply and Wages }\end{array}$ & 6 & $6 / 00$ \\
\hline 163 & $\begin{array}{l}\text { R. A. Hart } \\
\text { Y. Ma }\end{array}$ & Why do Firms Pay an Overtime Premium? & 5 & $6 / 00$ \\
\hline 164 & $\begin{array}{l}\text { M. A. Shields } \\
\text { S. Wheatley Price }\end{array}$ & $\begin{array}{l}\text { Racial Harassment, Job Satisfaction and Intentions } \\
\text { to Quit: Evidence from the British Nursing } \\
\text { Profession }\end{array}$ & 5 & $6 / 00$ \\
\hline 165 & P. J. Pedersen & $\begin{array}{l}\text { Immigration in a High Unemployment Economy: } \\
\text { The Recent Danish Experience }\end{array}$ & 1 & $6 / 00$ \\
\hline 166 & $\begin{array}{l}\text { Z. MacDonald } \\
\text { M. A. Shields }\end{array}$ & $\begin{array}{l}\text { The Impact of Alcohol Consumption on Occupa- } \\
\text { tional Attainment in England }\end{array}$ & 5 & $6 / 00$ \\
\hline 167 & $\begin{array}{l}\text { A. Barrett } \\
\text { J. FitzGerald } \\
\text { B. Nolan }\end{array}$ & $\begin{array}{l}\text { Earnings Inequality, Returns to Education and } \\
\text { Immigration into Ireland }\end{array}$ & 5 & $6 / 00$ \\
\hline 168 & $\begin{array}{l}\text { G. S. Epstein } \\
\text { A. L. Hillman }\end{array}$ & $\begin{array}{l}\text { Social Harmony at the Boundaries of the Welfare } \\
\text { State: Immigrants and Social Transfers }\end{array}$ & 3 & $6 / 00$ \\
\hline 169 & R. Winkelmann & $\begin{array}{l}\text { Immigration Policies and their Impact: The Case of } \\
\text { New Zealand and Australia }\end{array}$ & 1 & $7 / 00$ \\
\hline 170 & $\begin{array}{l}\text { T. K. Bauer } \\
\text { K. F. Zimmermann }\end{array}$ & $\begin{array}{l}\text { Immigration Policy in Integrated National } \\
\text { Economies }\end{array}$ & 1 & $7 / 00$ \\
\hline 171 & $\begin{array}{l}\text { C. Dustmann } \\
\text { F. Windmeijer }\end{array}$ & $\begin{array}{l}\text { Wages and the Demand for Health - A Life Cycle } \\
\text { Analysis }\end{array}$ & 5 & $7 / 00$ \\
\hline 172 & D. Card & $\begin{array}{l}\text { Reforming the Financial Incentives of the Welfare } \\
\text { System }\end{array}$ & 3 & $7 / 00$ \\
\hline 173 & D. S. Hamermesh & Timing, Togetherness and Time Windfalls & 5 & $7 / 00$ \\
\hline
\end{tabular}



M. Ward

180 T. K. Bauer I. N. Gang

E. Wasmer

Y. Zenou

184 M. Corak

B. Gustafsson

T. Österberg

185 H. Bonin

K. F. Zimmermann

A. S. Kalwij

A. Zaidi 
223 M. Rosholm

Wages, Training, and Job Turnover in a Search-

1 former Soviet Union to Israel: Who is coming when? 